\title{
Language, Gender and Sexuality
}

\author{
Melissa Yoong
}

\section{Introduction}

Language and gender is a rapidly expanding field within the larger study of sociolinguistics. Although language and gender studies are not always feminist in orientation, this is an area of academic enquiry with feminist roots, emerging in the early 1970s, possibly as a result of the women's liberation movements. While work on gender and the English language had existed prior to this, it was during this period that the interface between language and gender began to be examined in a systematic way (Mills and Mullany 2011), often with a political purpose. The majority of language and gender studies today continues to share the political goal of gender equality. While researchers are united by emancipatory aims, there is now a broad spectrum of research in a wide range of social contexts from a variety of theoretical positions.

This chapter will commence with a broad overview of early research that looked for differences between women's and men's language use, before turning to leading current perspectives that place emphasis on agency and diversity in the linguistic construction of gender identities. It will then discuss two crucial lines of inquiry within scholarly work applying these contemporary theoretical frameworks: how women leaders negotiate their professional identities through the use of language, and the various ways masculinities are linguistically constructed and inflected by sexuality. Following this, there will be a discussion of selected areas of debate, in particular those relating to the interactional salience of gender, and the use of the masculine/feminine dichotomy in the analysis of speech styles. The final section will put forward a series of recommendations for future language and gender research concerning the topics and issues examined in the chapter.

\section{Early approaches and pioneering research}

The main theoretical frameworks in early language and gender research are commonly known as the deficit, dominance and difference approaches (see Talbot 2010). While these paradigms are useful for tracing the field's chronological advancements, empirical work often drew on elements from more than one approach, and some did not fall under any particular theoretical category (Mullany 2010). Initial studies were driven by feminist concerns regarding the sociopolitical disparities between the sexes, and aimed to reveal the social subordination of women that was reflected in their linguistic subordination. Lakoff's (1975) Language and Woman's Place hypothesises that there is a distinct 'women's language' characterised by a lack 
of confidence, superpoliteness and weakness, mirroring women's subordinate status in society. This account is largely based on anecdotal observations, and unintentionally reinforces stereotypes and the deficit model of women's speech. Nevertheless, it was valuable as a springboard for academic research in the 1970s and 1980s that analysed the linguistic features of 'women's language', such as affective adjectives, hedges and tag questions.

Like Language and Woman's Place, Spender's (1980) Man Made Language focuses on differences between women's and men's language use. The theme of male dominance is central to this work, and its fundamental claim is that the English language is literally manmade and manifests a patriarchal social order. The book popularised the study of language and gender, and introduced a large audience to conventionalised sexism in the English language, highlighting examples such as male generics. However, it was widely criticised for its determinist notion of the relationship between language and reality as well as its highly monolithic view of language, male power and gender relations (see Black and Coward 1998).

Feminist linguists argued against the negative portrayal of women's language as weak and women as victims, and in the 1980s, research began to take a new perspective that conceived the differences in male and female language patterns not as male oppression of women, but as a 'cross-cultural' phenomenon arising from the single-sex sociolinguistic subcultures in which women and men are socialised as children. This 'two cultures approach' was initiated by Maltz and Borker (1982), who reinterpreted interactional difficulties between the sexes in earlier studies as miscommunication due to differing expectations of discourse. This offered linguists a way to conduct research beyond a dominance and oppression framework, and to celebrate 'women's talk'. Tannen (1991) adopted Maltz and Borker's explanatory framework in the bestseller You Just Don't Understand, in which she polarised and stereotyped women's and men's conversational styles, claiming, for example, that women look for intimacy through conversation, whereas men seek status. Tannen carefully maintained a neutral position, and received strong criticism for disregarding broader sociopolitical considerations and power asymmetries in gender relationships (Cameron 1992). The cross-cultural communication analogy was also questioned since women and men share linguistic worlds, including as children (Troemel-Ploetz 1991).

\section{Contemporary approaches}

While early research differentiated gender (learned behaviour) from sex (biologically based), 'the latter [was] implicitly assumed to provide the grounding for the former', resulting in the polarisation of women and men into homogenous groups (Cameron 2005: 484). Current investigations into language and gender predominantly adopt social-constructionist perspectives, which regard gender as something people do rather than have. The paradigm shift, observed in the 1990s, was influenced by Butler's (1990) model of performativity, which represents gender 
as dynamic, fluid and performatively constituted in interaction, rather than an inherent trait. Individuals are constantly negotiating and renegotiating their social identities, including their gender identity, and one of the ways of producing themselves as gendered beings is through their linguistic practices. In this sense, linguistic behaviour does not arise from a pre-existing gender identity, but rather, it is through repeated linguistic acts over time that gender identities are produced. However, while these practices are not automatically determined by biological sex, they are also not freely chosen, but constrained and conditioned by 'a rigid regulatory frame' (Butler 1990: 33). Deeply rooted social expectations of gender behaviour affect how an individual speaks in a particular context, and the 'masculine' and 'feminine' speech styles identified in research can be conceived as the congealed result of repeated enactments of what is considered socially acceptable gender identity (Cameron 1997). At the same time, Butler emphasises the individual's agency and ability to subvert societal norms and forces, sometimes with negative consequences.

Eckert and McConnell-Ginet's (1992) Communities of Practice framework complements the performativity model as it not only views gender as something that emerges from interaction, but also reconnects language use to social practices in local communities. Eckert and McConnellGinet (1999: 186) define a community of practice (CofP) as 'an aggregate of people who, united by a common enterprise, develop and share ways of doing things, ways of talking, beliefs, and values: in short, practices'. This framework allows analyses to be more sensitive to situationspecific expectations of linguistic behaviour and localised language patterns, and their relationship to the distinct and diverse gender identities constructed.

Two important theoretical developments bridge local language practices with the wider gender order, and are often integrated with the performativity approach and the CofP framework: Ochs's $(1990,1992)$ theory of 'indexicality', and the notion of gendered discourses (Sunderland 2004). Ochs argues that few lexical items have a direct indexical relationship with gender. On the other hand, manhood or womanhood tend to be indirectly indexed through language features that carry gendered meaning due to regular association with men or women. In order to interpret a speech pattern as indexing maleness or femaleness, the sociocultural context must be considered. Discourses, in this chapter, refer to 'practices that systematically form the objects of which they speak' (Foucault 1972: 49). 'Gendered discourses' can be seen as systems that 'carry' ideology and regulate gendered behaviour in society (Sunderland 2004: 3). Gendered discourses, such as the persistent discourse of gender differences, both constitute and are constituted by the social world.

The emphasis on context and local meanings has moved feminist linguistics from stereotyping male and female speech patterns to taking into account how the interlocutors' various social attributes, such as ethnicity, age, religion and social class, operate together with gender in complex ways to produce their linguistic behaviour. Within this approach, termed 
'intersectionality', identity is viewed not only as dynamic, but also as multidimensional, where different facets of social identity are instantiated and indexed via the use of language.

\section{Current critical issues and topics}

\section{Language and women's leadership in professional settings}

Language and gender studies largely have feminist intentions and aim to redress the gender disparities in society that are reflected in, and perpetuated by, language use. One significant aspect of gender inequality that continues to receive a great deal of attention in this field has been the lack of women in leadership roles in professional contexts, often referred to as the 'glass ceiling'. Although there has been an increasing number of female leaders in the workplace in recent decades, women's advancement still lags behind that of their male counterparts, and language is a powerful contributing factor behind the under-representation of women at leadership level (Baxter 2008).

Leadership discourse has two important functions: to promote organisational goals (transactional behaviour) and maintain good working relationships within the team (relational behaviour). Transactional behaviours that 'primarily aim at getting things done, solving problems and achieving set goals' are typically indexed for masculinity, whereas more relational practices that focus on 'ensuring group harmony and creating a productive working environment' are ascribed to femininity. In other words, the language and performance of leadership are gendered (Schnurr and Mak 2011: 348), despite growing evidence that women and men leaders utilise both stereotypical 'masculine' and 'feminine' linguistic behaviour, depending on their interactional context and aims (e.g. Holmes 2006; Mullany 2007). Holmes (2005: 49) argues that these 'gendered discourse patterns typically emphasise the power of the male, and underline the supportive role of the female in workplace interaction'.

In many workplaces, it is stereotypical 'masculine' discourse strategies, such being direct, assertive and outcome-oriented (Holmes and Stubbe 2003) that tend to be associated with leadership. Women moving into professional contexts where normatively masculine speech styles predominate sometimes adopt the masculine interactional behaviour of their CofP (Holmes 2006). However, this has not been successful in breaking the glass ceiling due to prevailing discourses of gender differences that 'systematically attribute quite rigid styles of speech and behaviour to males and to females', leading to women being judged differently from men for adopting equivalent communicative strategies (Baxter 2008: 201). For example, since assertiveness indexes masculinity, women are viewed as going against their gender when they are assertive in their language use (Holmes 2006), which can cause their behaviour to be perceived as threatening and unfeminine by their colleagues (Mullany 2007). 
Researchers have found that women in positions of authority often face a 'double bind' (e.g. Marra et al. 2006; Mullany 2011), that is:

if they interact in a stereotypically feminine manner they will be negatively evaluated for being an incompetent professional, whereas if they interact in a stereotypically masculine manner, using 'marked' linguistic forms, they will be negatively evaluated for being overly aggressive. (Mullany 2007: 32)

This is arguably why some women make the pragmatic choice to use tentative and indirect speech, rather than assert themselves, in the workplace (Crawford 1995). Barrett's (2004) study is an important example of this. She found that senior women in Australian workplaces, including those with high confidence, believe that the masculine model of communication is more valuable for achieving particular goals, but less effective for women in certain situations. Thus, even senior women favour more indirect, 'feminine' approaches. As Mills and Mullany (2011: 55) state,

women engage in a complex process whereby they assess others' stereotypical beliefs about gender and then tactically adopt strategies which will be most likely to achieve their ends; and some of those strategies may well be ones stereotypically associated with feminine language.

Nevertheless, it is becoming increasingly evident in research that many interactional styles associated with 'effective' leadership are indexed for femininity (Eagly and Carli 2003), and a more 'feminised' workplace culture that values relational leadership behaviour is emerging in international corporations (Cameron 2000). In such workplaces, discourse strategies typically associated with femininity, such as being indirect, conciliatory, supportive and collaborative (Holmes and Stubbe 2003), have been neutralised of their associations with gender, and institutionalised as integral management skills (Cameron 2000; Baxter 2008).

However, the shift towards a management style that combines transactional and relational aspects of leadership has not benefitted senior women (Baxter 2012). This is evident in Baxter's (2008: 217) study on how British business leaders discursively construct their leadership identities. She found that in addition to being celebrated for using relational forms of discourse, the men are tolerated or admired when they display authoritative behaviour, but the women are negatively assessed for doing the same and have to deploy a range of strategies to 'observe, regulate, police, review and repair the way they appear and sound to their colleagues', including preparing rigorously and using humour, mitigated commands and apologies. This pattern has also been identified in the Wellington Language in the Workplace Project, which analysed a corpus of over 1,500 recorded workplace interactions in New Zealand (e.g. Holmes and Stubbe 2003). Baxter (2008: 217) argues that this can weaken the impact of the women's talk, which 'may offer a linguistic reason why females still struggle to "make it to the top"'. 
This is not to imply that women are hapless victims in the workplace. Kendall (2003: 604) argues that some senior women who linguistically downplay status differences are not reluctant to exert authority, but are in fact exercising their authority 'by speaking in ways that accomplish work-related goals while maintaining the faces of their interlocutors'. Empirical evidence shows that women managers are capable of drawing on a wide repertoire of discursive styles in order to get certain business accomplished (Holmes and Stubbe 2003). Therefore, it is important to recognise women's agency in negotiating with an array of disabling constraints in order to meet their professional goals.

\section{The linguistic construction of masculinities}

Due to the political aims of language and gender research, studies in this field have largely focused on women's linguistic behaviour and the construction of women's identities through the use of language. Furthermore, women have been traditionally contrasted to men, who have been regarded as the norm or default as well as a homogeneous group. The lack of problematisation of men's language use, as Kiesling (2007) argues, has rendered men relatively invisible, and partly contributed to male dominance in society. However, scholarly work into the varied ways men use language to construct their multiple subjectivities and how these are shaped by discourses of masculinity has increased since the late 1990s.

Research has demonstrated that men often index hegemonic masculinity through an array of linguistic strategies (e.g. Coates 2003), where hegemonic masculinity is 'the qualities defined as manly that establish and legitimate a hierarchical and complementary relationship to femininity and that, by doing so, guarantee the dominant position of men and the subordination of women' (Schippers 2007: 94). These characteristics typically include leadership, heterosexuality and physical strength, though the culturally dominant notion of masculinity and how it is linguistically expressed is context-dependent. For example, in Wetherell and Edley's (1999) study, male students in a British university discursively position themselves as 'ordinary' (i.e. normal or average) or 'rebellious' (i.e. non-normative) rather than 'macho', thereby reinforcing their personal autonomy, which is a hegemonic ideal. On the other hand, in a fraternity party in a US university, members of this 'hypermasculine' CofP use competitive speech genres, such as insults, which Kiesling (2005) posits are the products of the conflict between achieving dominance and developing homosocial ties with other men. In a Malaysian phone-in radio show, the hegemonic features of idealised masculinity indexed by married male callers' talk include economic power and control over the household (Yoong 2017). Even though multiple masculinities exist, many men strive to emulate hegemonic masculinity as it is considered the ideal and allows them to tap into certain social privileges, and language is an important resource to articulate hegemonic masculine identities. 
Hegemonic masculinity is ideologically intertwined with heterosexuality. For instance, in order to construct their masculinity, the fraternity members in Cameron's (1997) work gossip about another man and construct him as gay, implying that they are not. By doing so, they are not only performing gender, but also doing sexuality. Although current scientific and political discourses categorically differentiate between gender and sexuality, the two dimensions inflect one another (Cameron 2005), and one recent development in the field of language and gender is the increasing focus on the relationship between gender and sexual identities, including nonnormative identities.

Research into queer men's and trans men's linguistic behaviour has provided a richer and more nuanced perspective of the myriad of ways masculinity can be achieved through the adoption of language indexical of the speaker's sexual identity. Various studies have described the range of ways gay men use language to index homosexuality rather than hegemonic, heteronormative masculinity (see Jones 2016). Conversely, Hazenberg's (2016: 289) study shows how avoidance strategies are central to the linguistic constructions of gender by straight men and transsexuals in Ottawa due to social stigma. While the former avoided sounding gay or effeminate to prevent any loss of social capital associated with heteronormative masculinity, the latter, who were at risk of violence, chose linguistic features that are 'neither markedly feminine nor markedly masculine, but nevertheless [fall] within the acceptable ranges of both' to ensure their gender performance was taken at face value.

By demonstrating that 'the performance of the gendered selves' was socially driven, Hazenberg's work picks apart the essentialist view that men (and women) possess inherent traits. As Milani (2011: 183) reminds us, alongside the important research on language, gender and 'liminal' sexual identities, critical analyses of heterosexual masculinities performed by men are necessary because from

the point of view of queer theory, we should not only pay attention 'to the cases in which bodies/relations/desires 'deviate' from the norm $:::$ it is through the deconstruction of what counts as 'normal' that we can undermine claims of biological and/or cultural essentialism, revealing instead the deeply social roots of such 'normality'.

Nevertheless, gender and sexuality is not the only potentially relevant combination of social identity categories. Language and masculinity studies adopting an intersectional perspective have been relatively rare, and Milani (2011: 181) makes the crucial observation that 'we still know too little about the ways in which ... social "othering" (Jaworski 2007) [along the lines of class and race] operates through language/discourse'. In one intersectional analysis, Baker and Levon (2016: 134) examine representations of various racialised and classed masculinities in the British print media between 2003 and 2011 to understand how these situate against each another within the broader ideological field of masculinity, and observe that 'black, Asian, working- and upperclass men are marginalised not (or not only) because of their race or social class, but because of 
the gendered connotations of these racial and social class positions'. Given that black and Asian masculinities 'realise a "patriarchal dividend" in certain contexts' (Baker and Levon 2016: 135) and upper-class men wield a considerable amount of social and material power over women and other men, it can be argued that there are multiple hegemonies, where certain masculine identities that are linked to social categories such as class and race exercise particular types of power over femininities and other masculinities depending on the context (Hearn and Morell 2012). Therefore, more intersectional analyses of masculinities are needed in language and gender research to understand the ideological organisation of specific configurations of masculinity with other axes of inequality.

\section{Key areas of debate}

\section{Interactional salience of gender}

In current theoretical approaches, gender is recognised as one of the several relevant analytical categories in the linguistic construction of complex social identities. Many researchers share the perspective that gender is an omni-relevant social category, including Holmes and Schnurr (2006: 33), who maintain that

gender is ... an ever-present influence on how we behave, and how we interpret others' behaviour, even if our level of awareness of this influence varies from one interaction to another, and from moment to moment within an interaction.

However, this is not wholly accepted, and over the past decades there has been an extensive discussion on gender salience in interactions. Schegloff (1997) argues against assuming that gender is always relevant as this could lead to scholars imposing their political concerns and their own ideas of what constitutes context onto interactions. Therefore, in order to remain objective, analysts should examine conversational behaviour from the micro-linguistic level of interactions and, if required, work up to the macro-level of political inequality, rather than the reverse. In other words, gender can only be considered as interactionally salient if it is explicitly signalled by the interlocutors, such as through self-repairs of gendered pronouns, and then becomes the topic of the conversation. In fact, for some researchers, even the use of gendered terms does not necessarily make gender a salient social variable. For example, in Kitzinger's (2007: 43) analysis of a recorded conversation on a helpline for women in trauma after childbirth, she argues that uses of 'women' and 'we women'

have less to do with gender and are much more directly related to the business of the helpline in delivering its advertised service. Gender is certainly not irrelevant to the interactional business being pursued here, but it is subordinated to, and in the service of, it. 
Critics of this approach, on the other hand, assert that broader sociocultural forces are at work within interactions, alongside the context explicitly invoked by the speakers (Mills and Mullany 2011). Holmes (2005) provides examples of workplace interactions in which gender is never made explicit, but operates in the background. In one case, a senior woman would speak authoritatively, and then mitigate the impact of her 'masculine' behaviour with a humorous comment - a pattern found in many studies, as discussed in the previous section. Therefore, to disregard the effects of implicit gendered expectations on interpersonal speech styles 'would be to miss out a crucial step in the analytical process, particularly when attempting to engage in politically active research' (Mills and Mullany 2011: 168). Weatherall (2000) also maintains that it would be unrealistic to expect feminist researchers not to draw on their values and political concerns. In fact, to focus on isolated segments of a conversation that explicitly orient to gender while ignoring the rest of the surrounding talk can be itself a non-neutral analytic decision (Stokoe and Smithson 2001). For certain researchers, such as Wetherell (1998), micro and macro-analysis each informs and lends meaning to the other, and rather than choosing between the two, they have successfully combined them in their studies.

Another issue with relying on the explicit mention of gender references is that since few English words directly index gender (Ochs 1992), this would limit admissible research data. Schegloff (1997: 182) addresses this by proposing that 'orientation to gender can be manifested without being explicitly named or mentioned'. Indirect indices of gender could include references to gendered activities, as well as 'ambiguous words with possible references to sexuality; reference to female appearance or male appearance; or references to female demeanor or male demeanor' (Hopper and LeBaron 1998: 171). Given that such terms are not intrinsically gendered, this would pose a conflict with Schegloff's overall stance since, as Stokoe and Smithson (2001) point out, it requires analysts to draw on implicit cultural knowledge. However, they also argue that despite the risk of misinterpretation, the inferential resources of analysts must be taken into account in order to produce an analytic study rather than a descriptive one.

Additionally, the habitual and repetitive re-enactments of 'feminising' or 'masculinising' acts, including through language behaviour, render the performance of gender invisible (Butler 1990). Therefore, even when gender may not be a conscious focus of identity performance, it may still be constructed linguistically. One could argue that if speakers uphold gender ideologies without being aware of making such language choices, this is all the more insidious for being instinctive (Widdowson 2007) as the more an ideology is taken for granted, the more powerful it becomes (Phillips 2003). Hence, it is the role of the analyst to expose gender discrimination and inequality that may have been previously unnoticed by the interactants. Nevertheless, in order to ensure their work is empirically grounded, it is important for researchers to think 'reflexively' about how their positions, values, experiences and biases may influence their research and interpretative capacity. 


\section{Approaches to analysing gendered speech styles}

Earlier in this chapter, we discussed how contemporary language and gender studies have adopted a more constructionist stance, where feminist linguists are concerned about how gender is negotiated locally within interaction, including through the use of gendered speech styles. Consequently, current research largely theorises speakers with reference to sociocultural stereotypes of femininity and masculinity. For example, stereotypically 'feminine' interactional styles include being indirect, deferent and facilitative, whereas 'masculine' speech is direct, assertive and competitive. This draws on the notion of categorical dichotomy in which 'there are two and only two categories (men and women, masculinity and femininity), and they are stereotypically opposite and homogeneous' (Kiesling 2007: 656).

Masculinity and femininity are not only defined in relation to each other, but also to men and women (Paechter 2006). This eliding of 'feminine' and 'masculine' speech styles with femaleness and maleness, which Butler (1990) argues are also cultural constructs, is problematic since 'by emphasizing language which reflects the [biological female-male dichotomy], linguists may be reinforcing biological essentialism, even if they emphasize that language, like gender, is learned behaviour' (Bing and Bergvall 1996: 18). It has also been subjected to critique for (inadvertently) reifying the gender binary, which 'glosses over the myriad identities within the broad categories of "masculine" and "feminine". It also ignores the gendered experiences of participants, particularly transsexuals' (Hazenberg 2016: 270). The trans men in Zimman's (2012) study, for example, do not switch from using aspects of language indexical of femininity to those indexing heteronormative cis (i.e. non-trans) masculinity, but perform complex gender identities that are specific to their personal experiences and how they see themselves, and do not fall on either side of the masculine/ feminine dichotomy perfectly.

Another problem with referencing stereotypical models of femininity and masculinity is that this could further entrench the association of feminine language with weakness and powerlessness. While masculinity and masculine language are conferred cultural power (Kiesling 2007), femininity is constructed as 'a variety of negations of the masculine' due to the dualistic relation between masculinity and femininity (Paechter 2006: 256). Consequently, as Holmes and Schnurr (2006) note, femininity is often associated with a lack of power and influence, and perceived as a negative attribute, which can have adverse implications. Their examination of interactional data from the Wellington Language in the Workplace Project, for example, demonstrates how men can face derision for using normatively feminine ways of talking within certain workplace cultures.

Critics have questioned if what have been termed as 'masculine' language features really index power and dominance, as claimed in previous research (see Coates 2003), given the indeterminacy of meaning for specific formal linguistic features (Toolan 1996). For instance, in early theorising, interrupting was viewed as a powerful strategy (Mills and Mullany 2011), and it 
was assumed that men not only interrupt more than women, but also interrupt women more than men (Kiesling 2007). However, the results of studies investigating this feature and gender have been inconclusive (see James and Clarke 1993). On the other hand, it has been found that speakers in positions of power tend not to interrupt since they are given more 'space' to speak. In contrast, those attempting to claim power use this linguistic form more (Diamond 1996; Manke 1997). Conversely, 'powerless' features may not be the simple markers of powerlessness as has been maintained (Mills 2012). Silence, which can be viewed as submissive and the opposite of interruption, may be a powerful feature when deployed by a man (Sattell 1983), whereas silence from a woman may be interpreted as weakness (Kiesling 2007). Likewise, O'Barr and Atkins (1980) found that women who do not use 'feminine' linguistic forms indexing deference are still perceived as speaking in a powerless way.

Mills and Mullany (2011) suggest developing new terms that transcend stereotypical feminine/masculine opposition and do not associate speech characteristics with gender. Rather than evaluating linguistic behaviour as masculine or feminine, Mills (2012) proposes the term 'discourse competence' to describe speech that applies co-operative and competitive strategies appropriately. She argues that 'feminine' and 'masculine' speech styles cannot be viewed as homogenous groupings of characteristics since both cover negative as well as positive elements. Therefore, discourse competence is achieved through a combination of co-operative and competitive strategies, and not normative masculinity. This can provide theorists with the space to classify the linguistic behaviour of strong female speakers as discursively competent, rather than deviant or 'masculine'. It also allows for the possibility to 'identify and describe women and men speakers who are displaying features of neither feminine or masculine speech behaviour, but who are simply competent speakers' (236) (see Sznycer 2013).

At the same time, Mills and Mullany (2011: 165) point out that 'developing non-gendered terms risks ignoring the meaning that those styles still have for many of the interactants'. As we have seen earlier, such as in our discussion of the 'double bind', the binary notion of gendered speech norms has deep social roots and greatly influences expectations of gender-appropriate language behaviour. While a large amount of language and gender scholarship has focused on women who adopt masculine speech norms, thereby 'challeng[ing] the notion that these are in fact masculine norms at all' (Mills 2012: 250) and 'dislocating masculinity' from men (Milani 2011: 183), Holmes (2007: 56-57) reminds us that "most of the world continues to treat "women" and "men", "female" and "male" as fundamental social categories, not least in describing interpersonal communication style'. Stereotypical feminine and masculine speech patterns are indirectly gender-indexed, and therefore strongly influence how we judge the linguistic behaviour of others. Speakers who 'fail to stay within the boundaries of gendered speech norms, Butler's (1990: 33) "rigid regulatory frame", : : : may well be subject to negative evaluation or abuse' (Mills and Mullany 2011: 53). Hence, although feminist academics may regard 'feminine' and 'masculine' speech norms as socially constructed, in order to challenge stereotypes and 
sociocultural expectations of female and male speech styles, references to stereotypical models of femininity and masculinity may be necessary.

\section{Future directions}

One significant area of research that needs to be given attention in the field of language and gender is the relationship between language, gender and postfeminism. Postfeminism is a sensibility that both invokes and rejects feminism with an emphasis on individualism, choice, empowerment, self-regulation, consumerism and sexual agency (Gill and Scharff 2011). It has been criticised for promoting myths that sustain the status quo, including the notion that gender equality has been achieved. Postfeminist narratives co-opt and universalise feminist discourses highlighting women's progress in certain societies while rejecting political aspects of feminism that direct attention to gender inequality since these hinder women from embracing their empowerment (Budgeon 2011). Lazar (2007: 154) criticises the seemingly emancipatory message that women can now 'have it all' if they try hard enough, as

[this] reframes women's struggles and accomplishments as a purely personal matter, thus obscuring the social and material constraints faced by different groups of women : : : A self-focused 'me-feminism' of this sort shifts attention away from the collective 'we feminism' needed for a transformational political program.

While many scholars from various disciplines in the arts, humanities and social sciences have highlighted the widespread proliferation of postfeminist rhetoric, and critiqued the resignification of freedom and agency and the resulting depoliticisation of gender equality (e.g. Gill and Scharff 2011), relatively little research into the ways that language is used to construct postfeminist narratives and subjects has been done in the field of language and gender, and this gap needs to be addressed.

As most language and gender studies have focused on cisgender people, or those implicitly presumed to be cisgender, due to their cultural privilege (Jones 2016), it is of crucial importance that research into the interplay between language, gender and sexual identities that have been typically perceived as deviant continues to expand. Linguists working within LGBT communities need to attend to an important concern that Hazenberg (2016) raises with regards to an intersectional conceptualisation of gender. For some researchers, gender and sexual identities, though not interchangeable, are closely linked. For example, in Cameron's (1997) analysis of interactions between fraternity members discussed earlier, hegemonic masculinity and heterosexuality are enacted simultaneously and inflect each other. However, Hazenberg (2016: 271, emphasis in original) argues that viewing gender and sexuality as inextricably intertwined is problematic: 
From the perspective advanced by many gender and queer activists (e.g. Burke 1996; Beasley 2005) - the two are clearly distinct: gender is an aspect of identity, of self, while sexuality is an aspect of desire, of attraction to others. Trans people in particular have fought long and hard to have their gender identities recognised as distinct from their sexual orientations ... For researchers working within marginalised communities, this can present a problem: do we recognise and maintain the separation that is so important to the people we are working with, or do we capitulate to the more widespread academic understanding of these phenomena, for the sake of clarity and consistency?

These are questions that require further consideration in the field. In Hazenberg's (2016) own study, discussed in the previous section, he uses a six-way gender split, categorising his participants as straight men, straight women, queer men, queer women, transsexual men and transsexual women. In so doing, Hazenberg (2016: 271) 'consolidate[s] the independent axes of gender and sexual orientation into a multi-dimensional space where both are equally important'.

The issue of self-identity and self-definition is related to the next recommendation. Given the unrelenting 'domination and exclusion based on people's gender and sexual identities' (CaldasCoulthard and Milani 2016: 147), it is of utmost importance that feminist linguists continue to feed developments in intellectual thought into practices both within and beyond academia to promote a better understanding of human diversity and bring about re-enactments of public policies. We need to pose more questions on how findings from intellectual inquiry can be translated to 'real world' contexts and eliminate gender and sexual discrimination. As Cameron (2007: 22) reminds us,

I did not become a feminist academic so I could talk to other feminist academics in our own intellectual space; I became a feminist academic because I wanted to challenge sexism. If we cease to do that, then in my view, nothing else we do will matter.

Finally, although the English language is used in most, if not all, parts of the world, studies have predominantly been conducted in Western locations. Research assessing the role that the English language plays in sustaining stereotypes and gender disparity has gradually expanded into previously under-researched countries and cultural contexts, and it is imperative that this continues so that gender inequalities globally are better represented, understood and deconstructed. This includes ensuring the complex intersection between language, gender and the fullest range of social identity categories is taken into consideration. For example, Mullany and Yoong's (2016) lexico-grammatical analysis of Malaysian media coverage of a parliamentary by-election demonstrates how a Malay Muslim politician's religion, race, sexuality and age intersected with her gender to constitute her as the less suitable candidate compared to her older, ethnically Chinese male opponent. Such research acknowledges that the ways that different groups of women materially experience gender discrimination vary according 
to their local context. Feminist linguistics needs to continue examining the diverse ways in which gender intersects with other social identity variables and systems of power.

\section{References}

Baker, P. and E. Levon (2016) "“That's what I call a man": Representations of racialised and classed masculinities in the UK print media', Gender and Language 10 (1): 106-139.

Barrett, M. (2004) 'Should they learn to interrupt? Workplace communication strategies Australian women managers forecast as effective', Women in Management Review 19 (8): 391-403.

Baxter, J. (2008) 'Is it tough talking at the top? A post-structuralist analysis of the construction of gendered speaker identities of British business leaders within interview narratives', Gender and Language 2 (2): 197-222.

Baxter, J. (2012) 'Women of the corporation: A sociolinguistic perspective of senior women's leadership language in the U.K', Journal of Sociolinguistics 16 (1): 81-107.

Beasley, C. (2005) Gender and Sexuality: Critical Theories, Critical Thinkers. London: Sage.

Bing, J. M. and V. L. Bergvall (1996) 'The question of questions: Beyond binary thinking', in V. L. Bergvall, J. M. Bing and A. F. Freed (eds), Rethinking Language and Gender Research: Theory and Practice. New York: Longman, 1-30.

Black, M. and R. Coward (1981) 'Linguistic, social and sexual relations: A review of dale spender's man-made language', Screen Education 39: 69-85.

Budgeon, S. (2011) 'The contradictions of successful femininity: Third wave feminism, postfeminism and "new" femininities', in R. Gill and C. Scharff (eds), New Femininities: Postfeminism, Neoliberalism and Subjectivity. Basingstoke: Palgrave Macmillan, 279-292.

Burke, P. (1996) Gender Shock: Exploding the Myths of Male and Female. New York: Anchor Books/ Doubleday. Butler, J. (1990) Gender Trouble: Feminism and the Subversion of Identity. New York: Routledge.

Caldas-Coulthard, C. R. and T. M. Milani (2016) 'Ten years of gender and language', Gender and Language 10 (2): 145-148.

Cameron, D. (1992) 'Review of Tannen 1991', Feminism and Psychology 2 (3): 465-489.

Cameron, D. (1997) 'Performing gender identity: Young men's talk and the construction of heterosexual masculinity', in J. Coates (ed.), Language and Gender: A Reader. Oxford: Blackwell, 270-284.

Cameron, D. (2000) Good To Talk: Living and Working in a Communication Culture. London: Sage. 
Cameron, D. (2005) 'Language, gender, and sexuality: Current issues and new directions', Applied Linguistics 26 (4): 482-502.

Cameron, D. (2007) 'Unanswered questions and unquestioned assumptions in the study of language and gender: Female verbal superiority', Gender and Language 1 (1): 15-25.

Coates, J. (2003) Men Talk: Stories in the Making of Masculinities. Oxford: Blackwell.

Crawford, M. (1995) Talking Difference: On Gender and Language. London: Sage.

Diamond, J. (1996) Status and Power in Verbal Interaction: A Study of Discourse in a CloseKnit Social Network. Amsterdam and Philadelphia: John Benjamins.

Eagly, A. H. and L. L. Carli (2003) 'The female advantage: An evaluation of the evidence', The Leadership Quarterly 14: 807-834.

Eckert, P. and S. McConnell-Ginet (1992) 'Think practically and look locally: Language and gender as community-based practice', Annual Review of Anthropology 21: 461-490.

Eckert, P. and S. McConnell-Ginet (1999) 'New generalisations and explanations in language and gender research', Language in Society 28 (2): 185-201.

Foucault, M. (1972) The Archaeology of Knowledge. London: Routledge.

Gill, R. and C. Scharff (eds) (2011) New Femininities: Postfeminism, Neoliberalism and Subjectivity. Basingstoke: Palgrave Macmillan.

Hazenberg, E. (2016) 'Walking the straight and narrow: Linguistic choice and gendered presentation', Gender and Language 10 (2): 270-294.

Hearn, J. and R. Morrell, (2012) 'Reviewing hegemonic masculinities and men in Sweden and South Africa', Men and Masculinities 15: 3-10.

Holmes, J. (2005) 'Power and discourse at work: Is gender relevant?', in M. M. Lazar (ed.), Feminist Critical Discourse Analysis: Gender, Power and Ideology in Discourse. Basingstoke: Palgrave, 31-60. H

olmes, J. (2006) Gendered Talk at Work. Oxford: Blackwell. Holmes, J. (2007) 'Social constructionism, postmodernism and feminist sociolinguistics', Gender and Language 1 (1): $51-78$.

Holmes, J. and S. Schnurr (2006) 'Doing femininity at work: More than just relational practice', Journal of Sociolinguistics 10 (1): 31-51.

Holmes, J. and M. Stubbe, (2003) 'Feminine workplaces: Stereotype and reality', in J. Holmes and M. Meyerhoff (eds), The Handbook of Language and Gender. Oxford: Blackwell, 573599.

Hopper, R. and C. LeBaron (1998) 'How gender creeps into talk', Research on Language and Social Interaction 31 (3): 59-74. 
James, D. and S. Clarke (1993) 'Women, men, and interruptions: A critical review', in D. Tannen (ed.), Gender and Conversational Interaction. New York: Oxford University Press, 231-280.

Jaworski, A. (2007) 'Language in the media: Authenticity and othering', in S. Johnson and A. Ensslin (eds.), Language in the Media: Representations, Identities, Ideologies. London: Continuum, 271-280.

Jones, L. (2016) 'Language and gender identities', in S. Preece (ed.), The Routledge Handbook of Language and Identity. Oxon: Routledge, 210-224.

Kendall, S. (2003) 'Creating gender demeanors of authority at work and at home', in J. Holmes and M. Meyerhoff (eds), The Handbook of Language and Gender. Oxford: Blackwell, 600623.

Kiesling, S. (2005) 'Homosocial desire in men's talk: Balancing and recreating cultural discourses of masculinity', Language in Society 34: 695-727.

Kiesling, S. (2007) 'Men, masculinities, and language', Language and Linguistics Compass 1: 653-673.

Kitzinger, C. (2007) ‘Is “woman” always relevantly gendered?' Gender and Language 1 (1): 3949.

Lakoff, R. (1975) Language and Woman's Place. New York. Harper and Row. Lazar, M. M. (2007) 'Feminist critical discourse analysis: Articulating a feminist discourse praxis', Critical Discourse Studies 4 (2): 141-164.

Maltz, D. and R. Borker (1982) 'A cultural approach to male-female miscommunication', in J. J. Gumperz (ed.), Language and Social Identity. Cambridge: Cambridge University Press, 196-216.

Manke, M. (1997) Classroom Power Relations: Understanding Student-Teacher Interaction. Mahwah, NJ and London: Lawrence Erlbaum Associates.

Marra, M., S. Schnurr and J. Holmes (2006) 'Effective leadership in New Zealand: Balancing gender and role', in J. Baxter (ed.), Speaking Out: The Female Voice in Public Contexts. Basingstoke: Palgrave, 240-260.

Milani, T. M. (2011) 'Introduction: Re-casting language and masculinities', Gender and Language 5 (2): 175-186. Mills, S. (2012) Gender Matters: Feminist Linguistic Analysis. London: Equinox.

Mills, S. and L. Mullany (2011) Language, Gender and Feminism: Theory, Methodology and Practice. Oxon: Routledge.

Mullany, L. (2007) Gendered Discourse in the Professional Workplace. Basingstoke: Palgrave. 
Mullany, L. J. (2010) 'Gender and interpersonal pragmatics', in M. A. Locher and S. L. Graham (eds), The Handbook of Interpersonal Pragmatics. Berlin: Mouton de Gruyter, 225-250.

Mullany, L. J. (2011) 'Discourse, gender and professional communication', in J. P. Gee and M. Handford (eds), The Handbook of Discourse Analysis. London: Routledge, 509-522.

Mullany, L. and M. Yoong (2016) 'Language, gender and identities in political life: A case study from Malaysia', in S. Preece (ed.), The Routledge Handbook of Language and Identity. Oxon: Routledge, 428-442.

O’Barr, W. and B. Atkins (1980) “'Women's language” or “powerless language”?' in S. McConnell- Ginet, R. Borker and N. Furman (eds), Women and Language in Literature and Society. New York: Praeger, 93-110.

Ochs, E. (1990) 'Indexicality and socialisation', in J. W. Stigler, R. A. Schweder and G. Herdt (eds), Cultural Psychology: The Chicago Symposia. Cambridge: Cambridge University Press, 287-308.

Ochs, E. (1992) 'Indexing gender', in A. Duranti and C. Goodwin (eds), Rethinking Context: Language as an Interactive Phenomenon. Cambridge: Cambridge University Press, 335358.

Paechter C. (2006) 'Masculine femininities/feminine masculinities: Power, identities and gender', Gender and Education 18 (3): 253-263.

Phillips, S. U. (2003) 'The power of gender ideologies in discourse', in J. Holmes and M. Meyerhoff (eds), The Handbook of Language and Gender. Oxford: Blackwell, 252-276.

Sattell, J. (1983) 'Men, inexpressiveness and power', in B. Thorne, C. Kramarae and N. Henley (eds), Language, Gender and Society. Rowley, MA: Newbury House, 118-124.

Schegloff, E. (1997) 'Whose text? whose context?' Discourse \& Society 8 (2): 165-185.

Schippers, M. (2007) 'Recovering the feminine other: Masculinity, femininity, and gender hegemony', Theory and Society 36 (1): 85-102.

Schnurr, S. and B. Mak (2011) 'Leadership in Hong Kong: Is gender really not an issue?' Gender and Language 5 (2): 343-371.

Spender, D. (1980) Man Made Language. London: Routledge \& Kegan Paul.

Stokoe, E. H. and J. Smithson (2001) 'Making gender relevant: Conversation analysis and gender categories in interaction', Discourse \& Society 12 (2): 217-244.

Sunderland, J. (2004) Gendered Discourses. Basingstoke: Palgrave. Sznycer, K. (2013) 'Strong female speakers: The resistant discourse of tennis players', Gender and Language 7 (3): 303-332.

Talbot, M. M. (2010) Language and Gender. 2nd edn. Cambridge: Polity Press. 
Tannen, D. (1991) You Just Don't Understand: Women and Men in Conversation. New York: William Morrow.

Toolan, M. (1996) Total Speech: An Integrational Linguistic Approach to Language. Durham, NC: Duke University Press.

Troemel-Ploetz, S. (1991) 'Selling the apolitical', Discourse and Society 2 (4): 489-502.

Weatherall, A. (2000) 'Gender relevance in talk-in-interaction and discourse', Discourse \& Society 11 (2): 286-288.

Wetherell, M. (1998) 'Positioning and interpretative repetoires: Conversation analysis and poststructuralism in dialogue', Discourse \& Society 9 (3): 387-412.

Wetherell, M. and N. Edley (1999) 'Negotiating hegemonic masculinity: Imaginary positions and psycho-discursive practices', Feminism and Psychology 9 (3): 335-356.

Widdowson, H. G. (2007) Discourse Analysis. Oxford: Oxford University Press. Yoong, M. (2017) 'Men and women on air: Gender stereotypes in humour sequences in a Malaysian radio phone-in programme', Gender and Language 11 (1): 30-50.

Zimman, L. (2012) Voices in Transition: Testosterone, Transmasculinity, and the Gendered Voice among Female-to-Male Transgender People (Unpublished PhD thesis, Boulder, Colorado: University of Colorado). 